Sains Malaysiana 50(10)(2021): 2945-2956

http://doi.org/10.17576/jsm-2021-5010-09

\title{
Sintesis, Aktiviti Antiplasmodium dan Kesitotoksikan secara in vitro Sebatian Porfirin Logam ke atas Strain Plasmodium falciparum K1
}

(Synthesis, in vitro Antiplasmodial Activity and Cytotoxicity of Metalloporphyrins against Plasmodium falciparum K1 Strain)

\author{
NuUr Haziqah Mohd Radzuan, Nur Aqilah Zahirah Norazmi, Amatul Hamizah Ali, Muntaz Abu

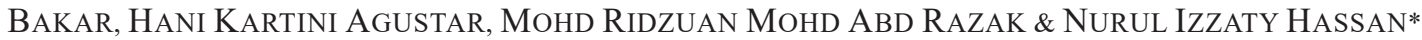

\begin{abstract}
ABSTRAK
Jangkitan malaria adalah penyakit berjangkit serius yang disebabkan oleh parasit plasmodium dan harus dirawat sebagai perubatan kecemasan. Sehingga kini, tiada vaksin yang sudah dikomersialkan untuk mencegah malaria. Enam sebatian porfirin logam nikel(II) dan zink(II) berasaskan porfirin meso bebas bes 5,15-difenilporfirin (2), 5,15-diheksilporfirin (3) dan 5,10,15,20-tetrafenilporfirin (4) iaitu NiDDHP, NiDPP, NiTPP, ZnDHP, ZnDPP dan ZnTPP dihasilkan melalui penyejatan Lindsey sebelum dicirikan secara spektroskopi (resonans magnet nukleus, ultra lembayung boleh nampak, spektrometri jisim) dan fizikal (takat lebur). Aktiviti antiplasmodium dan kesitotoksikan secara in vitro terhadap strain rintang-klorokuina, P. falciparum K1 dinilai dan dibandingkan dengan aktiviti antiplasmodium dadah rujukan seperti klorokuina dan artemisinin. ZnDHP, ZnTPP dan NiDPP merencat pertumbuhan parasit dengan 50\% kepekatan perencatan berkesan $\left(E C_{50}\right)$ dalam julat aktiviti antiplasmodium sederhana iaitu 21.4 sehingga 36.0 MM. Aktiviti kesitotoksikan terhadap sel mamalia Vero yang ditunjukkan oleh NiDPP, ZnDHP dan ZnTPP berada dalam julat tidak toksik iaitu 97 sehingga $587 \mu$ M. ZnDHP mempunyai nilai indeks pemilihan yang paling tinggi iaitu $27.2 \mu \mathrm{M}$, menunjukkan aktiviti antiplasmodium yang selektif terhadap perencatan plasmodium dan tidak toksik terhadap sel mamalia.
\end{abstract}

Kata kunci: Antiplasmodium; in vitro; kesitotoksikan; P. falciparum K1; porfirin logam

\section{ABSTRACT}

Malaria infection is a severe infectious disease caused by plasmodium parasites and should be treated as emergency medicine. Until now, no vaccine has been commercialized to prevent malaria. Six nickel(II) and zinc(II) metal porphyrin compounds based on free meso porphyrin base 5,15-diphenylporphrin (2), 5,15-dihexylporphyrin (3), and 5,10,15,20-tetraphenyl porphyrin (4), known as NiDDHP, NiDPP, NiTPP, ZnDHP, ZnDPP and ZnTPP are produced through Lindsey condensation before being characterized by spectroscopy (nuclear magnetic resonance, ultraviolet-visible spectrophotometry, mass spectrometry) and physical (melting point). In vitro antiplasmodial and cytotoxicity activities against the P. falciparum K1 strain were assessed and compared to the antiplasmodial activity of referral drugs such as chloroquine artemisinin. ZnDHP, ZnTPP and NiDPP recorded parasites' growth with 50\% effective inhibition concentration (EC $C_{50}$ ) in a range of 21.4 to $36.0 \mu M$. Cytotoxic activities of NiDPP, ZnDHP and ZnTPP against Vero mammalian cells were in a non-toxic range of about 97 to $587 \mu \mathrm{M}$. ZnDHP possessed the highest selectivity index value of $27.2 \mu \mathrm{M}$, indicating that the compound's antiplasmodial effect was a selective plasmodial inhibition and non-toxic to the mammalian cells.

Keywords: Antiplasmodial; cytotoxicity; in vitro; metalloporphyrin; P. falciparum K1

\section{Pengenalan}

Pelan Strategik Eliminasi Malaria Kebangsaan mensasarkan penurunan kejadian kes malaria dan mencapai status eliminasi malaria menjelang tahun 2020 .
Walau bagaimanapun, kes malaria masih lagi berlaku dalam kalangan rakyat Malaysia terutamanya di Sabah dan Sarawak disebabkan oleh kedatangan ramai pekerja asing dari negara jiran berdekatan (Hussin et al. 2020; Yong 
et al. 2018). Parasit plasmodium telah menghasilkan strain yang mempunyai kerintangan kimia terhadap ubatan klorokuina. Rawatan piawai yang sering digunakan untuk merawat malaria adalah terapi gabungan berasaskan artemisinin dan terbitannya (Li 2012). Keberkesanannya turut terancam apabila parasit malaria menjadi semakin berdaya tahan terhadap bahan aktif dalam gabungan tersebut (Fairhurst \& Dondorp 2016). Tambahan pula, akses kepada rawatan adalah sangat terhad dan memberi kesan besar kepada negara miskin dengan kos terapi yang tinggi (Hamed \& Stricker 2016).

Oleh itu, perlunya penyelidikan berterusan untuk menghasilkan ubat antimalaria baharu yang tidak menimbulkan daya tahan daripada parasit plasmodium (Ali et al. 2017). Antara pendekatan yang digunakan dalam penghasilan ubat antimalaria baharu adalah dengan menggabungkan struktur organik yang diketahui kebolehan antimalarianya bersama kompleks organologam (Dive \& Biot 2008). Kompleks organologam mempunyai kebolehan mengkoordinat ligan dalam konfigurasi tiga dimensi yang membolehkan pemfungsian sebatian ke atas molekul sasaran. Sebatian berasaskan logam, terutamanya logam peralihan mempunyai sifat-sifat unik yang membolehkan mereka diguna pakai dalam merawat penyakit (Navarro et al. 2012). Penggunaan ferrokuina sebagai rawatan alternatif malaria telah membawa kepada penemuan pelbagai kompleks organologam berasaskan moieti ferosil (Peter \& Aderibigbe 2019), makrosiklik tetraaza (Hubin et al. 2014) dan thiosemikarbazon (Summers 2019). Namun begitu, sintesis kompleks organologam makrosiklik tetraaza yang mengandungi moieti seperti siklen (Li et al. 2008) dan siklam (Banziger \& Ren 2019) melibatkan tindak balas yang banyak dan rumit.

Parasit malaria menghasilkan hem melalui pendegradan hemoglobin, dengan penghabluran hem dinyahtoksikkan untuk menghasilkan hemozoin. Hem ini dimusnahkan melalui tindak balas dengan hidrogen peroksida atau glutionin. Pempolimeran kepada $\beta$-hematin mencegah ketoksikan hem di samping menjadi sasaran utama terbitan dadah klorokuina. Sebatian porfirin logam dikenal pasti berpotensi untuk bertindak sebagai perencat poten bagi pempolimeran hem. Ion logam pusat pada porfirin logam memainkan peranan yang signifikan dalam merencatkan pempolimeran hem melalui interaksi $\pi-\pi$ di antara hem dan ion logam (Cole et al. 2000). Walau bagaimanapun, data efikasi sebatian porfirin logam bertindak sebagai agen antimalaria masih kurang meluas dilaporkan.

Penilaian aktiviti antiplasmodium secara in vitro bagi enam sebatian metaloporfirin iaitu NiDDHP,
NiDPP, NiTPP, ZnDHP, ZnDPP dan ZnTPP berasaskan porfirin meso bebas bes 5,15-difenilporfirin (2), 5,15-diheksilporfirin (3) dan 5,10,15,20-tetrafenilporfirin (4) dijalankan terhadap strain rintang-klorokuina $P$. falciparum K1. Aktiviti antimalaria diuji dengan kaedah asai plasmodium laktat dehidrogenase (pLDH) dan keputusannya dibandingkan dengan dadah rujukan klorokuina dan artemisinin (Okebe et al. 2014). Analisa kesitotoksikan turut dijalankan ke atas sel mamalia Vero menggunakan kaedah asai 3-(4,5-dimetiltiazol-2-il)-2,5difeniltetrazolium bromida (MTT) (Mamat et al. 2020). Nilai indeks pemilihan (SI) bagi setiap sebatian porfirin logam ditentukan berdasarkan nilai kepekatan pada 50\% pertumbuhan daripada kedua-dua asai antimalaria dan kesitotoksikan.

\section{BAHAN KIMIA DAN INSTRUMENTASI}

Bahan kimia utama yang digunakan adalah pirola $98 \%$ (Sigma Aldrich), benzaldehid (R\&M), asid trifloroasetik 99\% (TFA) (Sigma Aldrich), fosforus pentaoksida $\left(\mathrm{P}_{2} \mathrm{O}_{5}\right)$, 2,3-dikloro-5,6-disiano-1,4-benzakuinon (DDQ) (Sigma Aldrich), trietilamina (TEA), N-bromosuksinimida (NBS), piridina, pinakolborana 97\% (Sigma Aldrich), mangkin paladium (Sigma Aldrich), 4-bromobenzaldehid dan heptanal. Manakala pelarut yang digunakan adalah diklorometana (DCM), metanol $(\mathrm{MeOH})$, kloroform $\left(\mathrm{CHCl}_{3}\right)$, heksana, 1,2-dikloroetana dan toluena, tetrahidrofuran (THF) dan dimetilformamida (DMF). Bagi setiap tindak balas yang dilakukan, pemantauan ketulenan awal sebatian dilakukan dengan teknik kromatografi lapisan nipis (KLN) $0.25 \mathrm{~mm}$ piring plat gel silika (Merck Kiesegel 60F254 penunjuk UL). Pencirian sebatian dilakukan dengan menggunakan spektroskopi Resonans Magnetik Nuklear, RMN (Bruker FT-NMR $100 \mathrm{MHz}$ dan $400 \mathrm{MHz}$ ), spektroskopi Ultralembayung Boleh Nampak, ULBN (Shimadzu UV1650 ) dengan pelarut DCM pada kepekatan $4 \times 10^{-6}$ $\mathrm{M}$ dan spektrometri jisim (Bruker MicroTof-Q) melalui kaedah direct infuse menggunakan elektrosemburan pengionan lembut (ESI). Pengukuran takat lebur diukur dengan Barnstead Electrothermal IA9000 Series dengan julat suhu sekitar suhu bilik hingga $400{ }^{\circ} \mathrm{C}$.

\section{SINTESIS SEBATIAN BAHAN PEMULA PORFIRIN DAN PORFIRIN LOGAM}

Kajian ini melibatkan dua peringkat tindak balas utama. Peringkat pertama melibatkan sintesis bahan pemula porfirin dan sebatian porfirin (Rajah 1). Untuk penghasilan sebatian porfirin 2-4, kaedah penyejatan Lindsey (Lindsey et al. 1987) yang melibatkan dua tindak 
balas utama iaitu tindak balas penyejatan dan diikuti dengan tindak balas pengoksidaan telah digunakan. Kaedah penyejatan ini melibatkan penggunaan pelarut DCM dan asid trifloroasetik sebagai bahan pemangkin.
Agen pengoksidaan yang digunakan bagi tindak balas ini adalah 2,3-dikloro-5,6-disiano-1,4-benzokuinona (DDQ). Peringkat kedua melibatkan penambahan logam ke dalam struktur sebatian porfirin untuk menghasilkan sebatian porfirin logam.

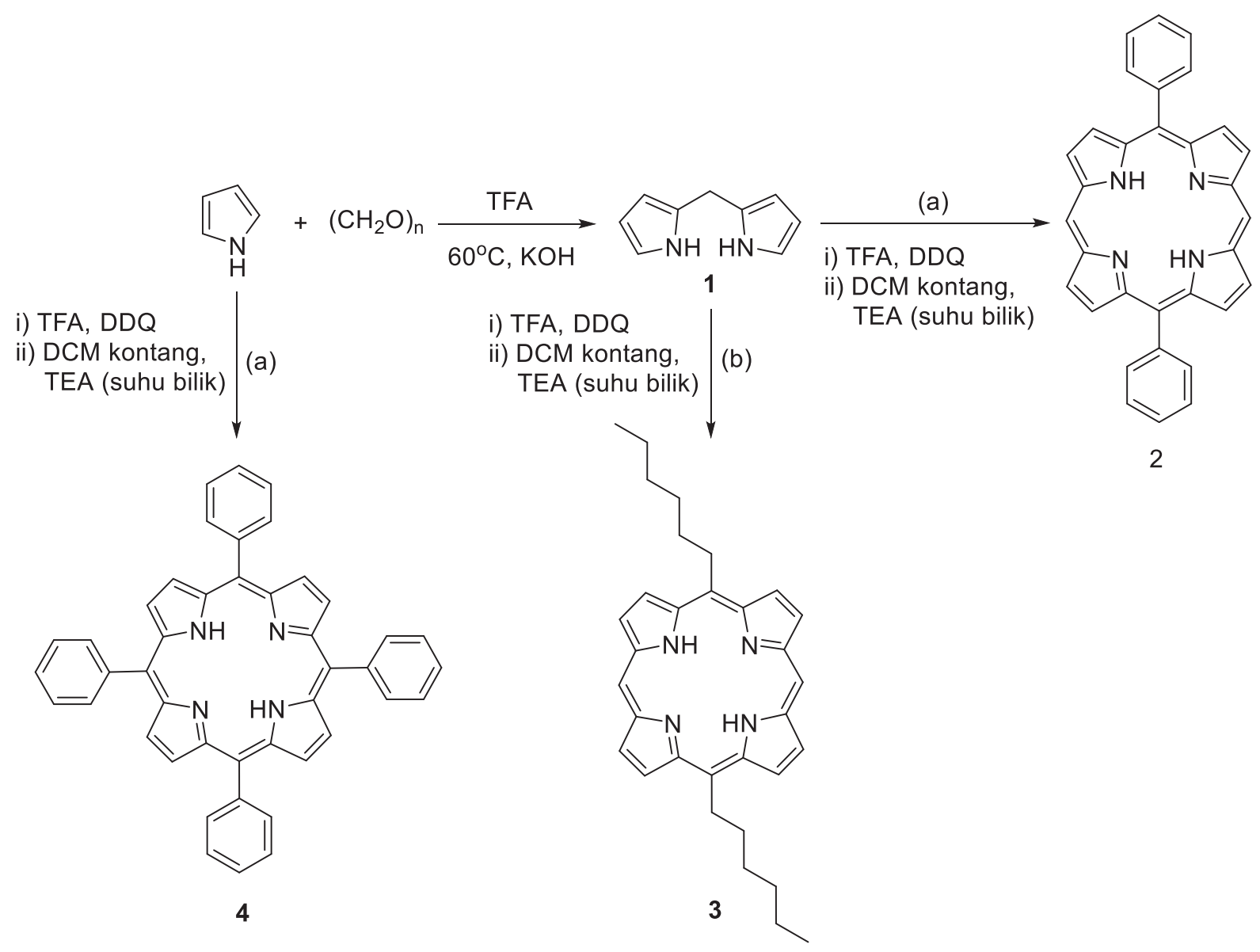

RAJAH 1. Skema tindak balas bagi pembentukan dipirometana dan sebatian porfirin: 5,15-difenilporfirin (2), 5,15-diheksilporfirin (3) dan 5,10,15,20-tetrafenilporfirin (4). (a) dan (b) merujuk kepada jenis aldehid yang digunakan iaitu (a) benzaldehid dan (b) heptaldehid

\section{SINTESIS SEBATIAN DIPIROMETANA (1)}

Paraformaldehid (3.46 g, $120 \mathrm{mmol}$ ) dikacau bersama dengan pirola $(200 \mathrm{~mL}, 2.80 \mathrm{~mol})$ dalam kelalang bulat berkepala tiga yang disertakan dengan termometer dalam posisi refluks. Asid trifloroasetik (TFA) $(0.2 \mathrm{~mL}, 2.60$ mmol) ditambah selepas campuran mencapai suhu 50 $-70{ }^{\circ} \mathrm{C}$. Potasium hidroksida $(\mathrm{KOH})$ ditambah pada suhu tidak melebihi $90{ }^{\circ} \mathrm{C}$ selama 30 min sebelum tindak balas ditamatkan. Sebatian diasingkan melalui kromatografi cecair vakum (KCV) dengan pelarut DCM, dipekatkan dan ditulenkan menggunakan teknik Kugelrohr untuk menghasilkan (1) sebagai hablur tidak berwarna.

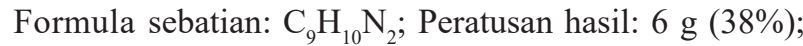
$\mathrm{RMN}^{1} \mathrm{H}\left(400 \mathrm{MHz}, \mathrm{CDCl}_{3}\right) \delta_{\mathrm{H}}: 3.97(\mathrm{~s}, 2 \mathrm{H}), 6.10\left(\mathrm{~d},{ }^{3} \mathrm{~J}_{\mathrm{HH}}\right.$ $=0.8 \mathrm{~Hz}, 2 \mathrm{H}), 6.22\left(\mathrm{q}, \mathrm{J}_{\mathrm{HH}}=2.8 \mathrm{~Hz}, 2 \mathrm{H}\right), 6.64\left(\mathrm{q}, \mathrm{J}_{\mathrm{HH}}=\right.$ $2.2 \mathrm{~Hz}, 2 \mathrm{H}), 7.70(\mathrm{~s}, 2 \mathrm{H}) \mathrm{ppm} . \mathrm{RMN}{ }^{13} \mathrm{C}\left(\mathrm{CDCl}_{3}\right) \delta \mathrm{C}: 26.3$, $106.1,108.4,117.1,128.8,129.3 \mathrm{ppm}$. 
SINTESIS SEBATIAN PORFIRIN 5,15-DIFENILPORFIRIN (2)

Dipirometana (1) (1.0 g, $6.80 \mathrm{mmol})$ dan benzaldehid di dalam DCM $(700 \mathrm{~mL})$ dengan kehadiran TFA $(0.1 \mathrm{~mL})$ ditindak balas selama 18 jam pada suhu bilik dengan pengaliran gas nitrogen berterusan. Selepas 18 jam, DDQ (2.5 g, $11 \mathrm{mmol}$ ) ditambah dan tindak balas diteruskan selama satu jam. Trietilamina (TEA) $(5 \mathrm{~mL})$ ditambah untuk melengkapkan tindak balas. Sebatian diasingkan dengan teknik KCV dan pelarut disingkirkan dengan alat penyejat berputar. Proses penghabluran semula dilakukan menggunakan sistem dua pelarut iaitu DCM dan metanol untuk menghasilkan (2) sebagai hablur berwarna ungu gelap. Formula sebatian: $\mathrm{C}_{32} \mathrm{H}_{22} \mathrm{~N}_{4}$; Peratusan hasil: $490 \mathrm{mg}$ (35\%); Takat lebur: $>300^{\circ} \mathrm{C} ; \mathrm{R}_{\mathrm{f}}$ (heksana: $\left.\mathrm{DCM}, 3: 2\right)$ : 0.4; RMN ${ }^{1} \mathrm{H}\left(400 \mathrm{MHz}, \mathrm{CDCl}_{3}\right) \delta \mathrm{H}:-3.09$ (s, 2H), 7.85 (m, $6 \mathrm{H}), 8.31\left(\mathrm{~d},{ }^{3} \mathrm{~J}_{\mathrm{HH}}=3.2 \mathrm{~Hz}, 4 \mathrm{H}\right), 9.13\left(\mathrm{~d},{ }^{3} \mathrm{~J}_{\mathrm{HH}}=4.4 \mathrm{~Hz}, 4 \mathrm{H}\right)$, $9.42\left(\mathrm{~d},{ }^{3} \mathrm{~J}_{\mathrm{HH}}=4.4 \mathrm{~Hz}, 4 \mathrm{H}\right), 10.34(\mathrm{~s}, 2 \mathrm{H}) \mathrm{ppm} ; \mathrm{RMN}^{13} \mathrm{C}$ $\left(100.6 \mathrm{MHz}, \mathrm{CDCl}_{3}\right) \delta \mathrm{C}: 105.3,119.1,127.0,127.8,131.1$, $131.7,134.9,141.4,145.2,147.2$ ppm; ULBN $\left(\mathrm{CH}_{2} \mathrm{Cl}_{2}\right)$ $\lambda_{\text {mak }} \mathrm{nm}(\log \varepsilon): 405$ (5.25), 497 (4.15), 537 (4.02), 572 (4.01), 627 (3.91); ESI-SJ (m/z): $462.18\left[\mathrm{M}^{+}\right]$.

\section{SINTESIS SEBATIAN 5,15 -DIHEKSILPORFIRIN (3)}

Dipirometana (1) (1.0 g, $6.80 \mathrm{mmol})$ dan heptaldehid (0.8 $\mathrm{mL}, 6.80 \mathrm{mmol})$ ditindakbalaskan bagi menghasilkan sebatian (3) iaitu hablur berwarna ungu gelap. Formula sebatian: $\mathrm{C}_{32} \mathrm{H}_{38} \mathrm{~N}_{4}$; Peratusan hasil: $370 \mathrm{mg}(23 \%)$; Takat lebur: $240-250{ }^{\circ} \mathrm{C}$; $\mathrm{R}_{\mathrm{f}}$ (heksana: DCM, 1:1): 0.5; RMN ${ }^{1} \mathrm{H}\left(400 \mathrm{MHz}, \mathrm{CDCl}_{3}\right) \delta_{\mathrm{H}}:-2.95(\mathrm{~s}, 2 \mathrm{H}), 0.97\left(\mathrm{t}, \mathrm{J}_{\mathrm{HH}}=7.2\right.$ $\mathrm{Hz}, 6 \mathrm{H}), 1.43$ (m, 4H), $1.56(\mathrm{~m}, 4 \mathrm{H}), 1.84(\mathrm{~m}, 4 \mathrm{H}), 2.57$ $(\mathrm{m}, 4 \mathrm{H}), 5.00\left(\mathrm{t}, \mathrm{J}_{\mathrm{HH}}=8.0 \mathrm{~Hz}, 4 \mathrm{H}\right), 9.41\left(\mathrm{~d},{ }^{3} \mathrm{~J}_{\mathrm{HH}}=4.4 \mathrm{~Hz}\right.$, $2 \mathrm{H}), 9.58\left(\mathrm{~d},{ }^{3} \mathrm{~J}_{\mathrm{HH}}=4.4 \mathrm{~Hz}, 4 \mathrm{H}\right), 10.17(\mathrm{~s}, 2 \mathrm{H}) \mathrm{ppm}$; RMN ${ }^{13} \mathrm{C}\left(100.6 \mathrm{MHz}, \mathrm{CDCl}_{3}\right) \delta_{\mathrm{C}}: 14.2,22.8,30.3,31.9,34.7$, $38.7,104.3,118.8,127.8,131.9,144.2,147.8$ ppm; ULBN $\left(\mathrm{CH}_{2} \mathrm{Cl}_{2}\right): \lambda_{\text {mak }} \mathrm{nm}(\log \varepsilon)=403(5.36), 501$ (4.26), 534 (4.02), 577 (4.03), 629 (3.92); ESI-SJ (m/z): $478.31[\mathrm{M}]^{+}$.

\section{SINTESIS SEBATIAN 5,10,15,20-TETRAFENILPORFIRIN (4)}

Sebatian 5,10,15,20-tetrafenilporfirin (4) disediakan menggunakan pirola $(5.25 \mathrm{~mL}, 75 \mathrm{mmol})$, benzaldehid (7.6 mL, $74 \mathrm{mmol})$, TFA (0.9 mL, $12 \mathrm{mmol})$ dan DDQ (2 g, $8.8 \mathrm{mmol})$. Pemisahan sebatian dilakukan dengan teknik KCV. Proses pengkristalan semula dilakukan dengan pelarut DCM dan $\mathrm{MeOH}$ untuk menghasilkan (4) iaitu hablur berwarna ungu gelap. Formula sebatian: $\mathrm{C}_{44} \mathrm{H}_{30} \mathrm{~N}_{4}$; Peratusan hasil: $300 \mathrm{mg}$ (1.0\%); Takat lebur: $399^{\circ} \mathrm{C}$; $\mathrm{R}_{\mathrm{f}}$ (heksana: DCM, 3:2): 0.7; RMN ${ }^{1} \mathrm{H}\left(400 \mathrm{MHz} \mathrm{CDCl}_{3}\right) \delta_{\mathrm{H}}$ : $-2.70(\mathrm{~s}, 2 \mathrm{H}), 7.82(\mathrm{~m}, 8 \mathrm{H}), 8.29\left(\mathrm{dd},{ }^{3} \mathrm{~J}_{\mathrm{HH}}=7.2 \mathrm{~Hz},{ }^{4} \mathrm{~J}_{\mathrm{HH}}\right.$ $=1.2 \mathrm{~Hz}, 8 \mathrm{H}), 8.92(\mathrm{~s}, 8 \mathrm{H}) \mathrm{ppm} ; \mathrm{RMN}{ }^{13} \mathrm{C}(100.6 \mathrm{MHz}$, $\left.\mathrm{CDCl}_{3}\right) \delta_{\mathrm{C}}: 120.2,126.7,127.8,131.1,134.6,142.2 \mathrm{ppm}$;
$\operatorname{ULBN}\left(\mathrm{CH}_{2} \mathrm{Cl}_{2}\right): \lambda_{\text {mak }} \mathrm{nm}(\log \varepsilon)=417$ (5.23), 509 (3.78), 546 (3.48), 589 (3.35), 646 (3.24); ESI-SJ (m/z): 615.2 $[\mathrm{M}+\mathrm{H}]^{+}$.

\section{SINTESIS SEBATIAN PORFIRIM LOGAM NI-5,15- DIHEKSILPORFIRIN (NiDPP)}

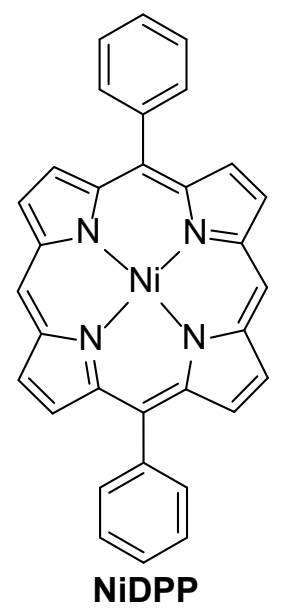

Sebatian porfirin 5,15-difenilporfirin (2) (50 mg, $0.1 \mathrm{mmol})$ dan nikel asetilasetonat, $\mathrm{Ni}(\mathrm{acac})_{2}(300 \mathrm{mg}, 1.2 \mathrm{mmol})$ dalam pelarut toluena direfluks selama tiga jam. Proses penghabluran semula oleh pelarut kloroform dan heksana menghasilkan sebatian NiDPPP iaitu hablur berwarna ungu kemerahan. Formula sebatian: $\mathrm{C}_{32} \mathrm{H}_{40} \mathrm{~N}_{4} \mathrm{Ni}$; Peratusan hasil: $15 \mathrm{mg}(30 \%)$. Takat lebur: $366{ }^{\circ} \mathrm{C}$; $\mathrm{R}_{\mathrm{f}}$ (heksana: kloroform, 2:1): 0.7. RMN ${ }^{1} \mathrm{H}\left(400 \mathrm{MHz} \mathrm{CDCl}_{3}\right) \delta_{\mathrm{H}}$ : $7.76(\mathrm{~m}, 6 \mathrm{H}), 8.10\left(\mathrm{~d},{ }^{3} \mathrm{~J}_{\mathrm{HH}}=5.2 \mathrm{~Hz}\right), 8.96\left(\mathrm{~d},{ }^{3} \mathrm{~J}_{\mathrm{HH}}=4 \mathrm{~Hz}\right.$, $4 \mathrm{H}), 9.22\left(\mathrm{~d},{ }^{3} \mathrm{~J}_{\mathrm{HH}}=4.4 \mathrm{~Hz}, 4 \mathrm{H}\right), 9.97(\mathrm{~s}, 2 \mathrm{H}) \mathrm{ppm}$; ULBN $\left(\mathrm{CH}_{2} \mathrm{Cl}_{2}\right): \lambda_{\text {mak }} \mathrm{nm}(\log \varepsilon)=399$ (5.13), 511 (3.94), 546 (3.65); EI-SJ (m/z): $518\left[\mathrm{M}^{+}\right]$.

SINTESIS SEBATIAN PORFIRIN LOGAM ZN-5,15DIHEKSILPORFIRIN (ZnDPP)

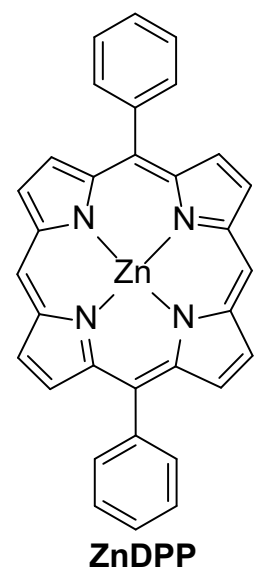


Sebatian porfirin 5,15-difenilporfirin (2) (50 mg, $0.1 \mathrm{mmol}$ ) dilarutkan dalam kloroform $(10 \mathrm{~mL})$ dan direfluks selama $10 \mathrm{~min}$. Sebatian zink asetat, $\mathrm{Zn}(\mathrm{OAc}),(50 \mathrm{mg}, 0.28$ mmol) dilarutkan dengan $\mathrm{MeOH}$ sebelum dimasukkan ke dalam campuran menggunakan kelalang penitis. Tindak balas dipantau menggunakan teknik KLN selepas 15 min. Proses penulenan melalui teknik penghabluran semula (DCM:MeOH) menghasilkan ZnDPP iaitu pepejal berwarna ungu kemerahan. Formula sebatian: $\mathrm{C}_{32} \mathrm{H}_{20} \mathrm{~N}_{4} \mathrm{Zn}$; Peratusan hasil: $56 \mathrm{mg}$ (99\%); Takat lebur: $360{ }^{\circ} \mathrm{C} ; \mathrm{R}_{\mathrm{f}}$ (heksana: kloroform, 1:1): 0.6; RMN ${ }^{1} \mathrm{H}(400$ $\left.\mathrm{MHz}, \mathrm{CDCl}_{3}\right) \delta_{\mathrm{H}}: 7.83(\mathrm{~m}, 6 \mathrm{H}), 8.30\left(\mathrm{dd},{ }^{3} \mathrm{~J}_{\mathrm{HH}}=6.8 \mathrm{~Hz}\right.$, $\left.{ }^{4} \mathrm{~J}_{\mathrm{HH}}=1.6 \mathrm{~Hz}, 4 \mathrm{H}\right), 9.18\left(\mathrm{~d},{ }^{3} \mathrm{~J}_{\mathrm{HH}}=4.4 \mathrm{~Hz}, 4 \mathrm{H}\right), 9.48\left(\mathrm{~d},{ }^{3} \mathrm{~J}_{\mathrm{HH}}\right.$ $=4.40 \mathrm{~Hz}, 4 \mathrm{H}), 10.37(\mathrm{~s}, 2 \mathrm{H}) \mathrm{ppm} ; \operatorname{ULBN}\left(\mathrm{CH}_{2} \mathrm{Cl}_{2}\right): \lambda_{\text {mak }}$ $\mathrm{nm}(\log \varepsilon)=407$ (5.27), 532 (3.79); EI-SJ (m/z): $524[\mathrm{M}]^{+}$.

\section{SINTESIS SEBATIAN PORFIRINLOGAM NI-5,15- DIHEKSILPORFIRIN (NiDHP)}

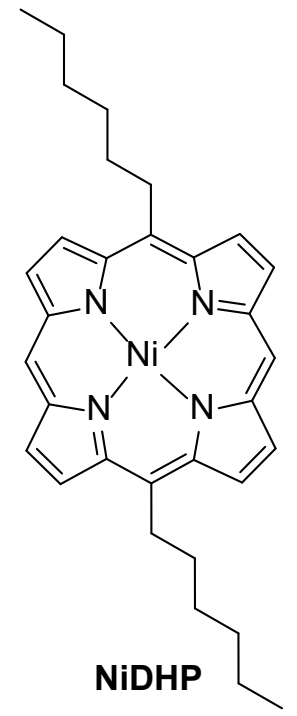

Sebatian porfirin logam NiDHP dihasilkan menggunakan sebatian porfirin (3) $(50 \mathrm{mg}, 0.1 \mathrm{mmol})$ dan $\mathrm{Ni}(\text { acac })_{2}$ (350 mg, $1.2 \mathrm{mmol}$ ). Proses penghabluran semula oleh pelarut kloroform dan heksana menghasilkan NiDHP iaitu hablur berwarna ungu kemerahan. Formula sebatian: $\mathrm{C}_{32} \mathrm{H}_{36} \mathrm{~N}_{4} \mathrm{Ni}$; Peratusan hasil: $46 \mathrm{mg}(82 \%)$; Takat lebur: $384{ }^{\circ} \mathrm{C}$; $\mathrm{R}_{\mathrm{f}}$ (heksana: kloroform, 2:1): 0.5; RMN ${ }^{1} \mathrm{H}(400$ $\left.\mathrm{MHz}, \mathrm{CDCl}_{3}\right) \delta_{\mathrm{H}}: 0.93\left(\mathrm{t}, \mathrm{J}_{\mathrm{HH}}=7.2 \mathrm{~Hz}, 6 \mathrm{H}\right), 1.38(\mathrm{~m}, 4 \mathrm{H})$, $1.47(\mathrm{~m}, 4 \mathrm{H}), 1.68(\mathrm{~m}, 4 \mathrm{H}), 2.39(\mathrm{~m}, 4 \mathrm{H}), 4.70\left(\mathrm{t}, \mathrm{J}_{\mathrm{HH}}=8.2\right.$ $\mathrm{Hz}, 4 \mathrm{H}), 9.20\left(\mathrm{~d},{ }^{3} \mathrm{~J}_{\mathrm{HH}}=4.8 \mathrm{~Hz}, 4 \mathrm{H}\right), 9.47\left(\mathrm{~d},{ }^{3} \mathrm{~J}_{\mathrm{HH}}=4.8 \mathrm{~Hz}\right.$, 4H), 9.74 (s, 2H) ppm; RMN 13C (75 MHz, CDCl $) \delta \mathrm{C}$ : 14.12, 22.70, 30.14, 31.81 , 34.21, 37.06, 103.83, 117.26, $129.31,132.06,141.38,142.53 ; \operatorname{ULBN}\left(\mathrm{CH}_{2} \mathrm{Cl}_{2}\right): \lambda_{\text {mak }} \mathrm{nm}$ $(\log \varepsilon)=400$ (5.25), 515 (4.04), 549. EI-SJ (m/z): 534.23 .
SINTESIS SEBATIAN PORFIRIN LOGAM Zn-5,15DIHEKSILPORFIRIN (ZnDHP)

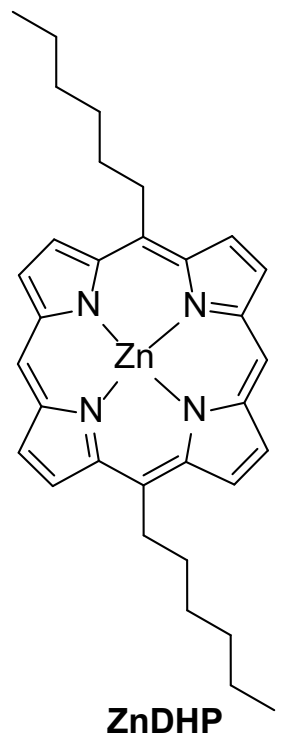

Sebatian porfirin logam ZnDHP dihasilkan menggunakan sebatian porfirin (3) $(50 \mathrm{mg}, 0.1 \mathrm{mmol})$ dan $\mathrm{Zn}(\mathrm{OAc})_{2}$ (350 mg, $1.2 \mathrm{mmol}$ ). Proses penghabluran semula oleh pelarut kloroform dan heksana menghasilkan ZnDHP iaitu hablur berwarna ungu kemerahan. Formula sebatian: $\mathrm{C}_{32} \mathrm{H}_{36} \mathrm{~N}_{4} \mathrm{Zn}$; Peratusan hasil: $50 \mathrm{mg}(88 \%)$; Takat lebur: $350{ }^{\circ} \mathrm{C} ; \mathrm{R}_{\mathrm{f}}$ (kloroform): 0.5; RMN ${ }^{1} \mathrm{H}\left(400 \mathrm{MHz}, \mathrm{CDCl}_{3}\right)$ $\delta_{\mathrm{H}}: 0.98\left(\mathrm{t}, \mathrm{J}_{\mathrm{HH}}=6.2 \mathrm{~Hz}, 6 \mathrm{H}\right), 1.27(\mathrm{~m}, 4 \mathrm{H}), 1.46(\mathrm{~m}, 4 \mathrm{H})$, $1.87(\mathrm{~m}, 4 \mathrm{H}), 2.61(\mathrm{~m}, 4 \mathrm{H}), 5.07\left(\mathrm{t}, \mathrm{J}_{\mathrm{HH}}=7.2 \mathrm{~Hz}, 4 \mathrm{H}\right), 9.45$ $\left(\mathrm{d},{ }^{3} \mathrm{~J}_{\mathrm{HH}}=2.0 \mathrm{~Hz}, 4 \mathrm{H}\right), 9.69\left(\mathrm{~d},{ }^{3} \mathrm{~J}_{\mathrm{HH}}=2.0 \mathrm{~Hz}, 4 \mathrm{H}\right), 10.14(\mathrm{~s}$, 2H) ppm; ULBN $\left(\mathrm{CH}_{2} \mathrm{Cl}_{2}\right): \lambda_{\text {mak }} \mathrm{nm}(\log \varepsilon)=406$ (5.25), 536 (3.80); EI-SJ (m/z): 540.22.

SINTESIS SEBATIAN PORFIRIN LOGAM NI-5,10,15,20TETRAFENILPORFIRIN (NiTPP)

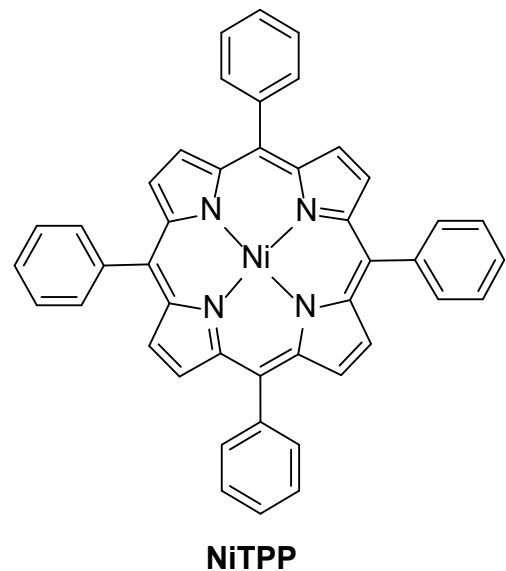


Sebatian porfirin logam NiTPP dihasilkan dengan menggunakan sebatian porfirin (4) (50 mg, $0.03 \mathrm{mmol})$ dan $\mathrm{Ni}(\mathrm{acac})_{2}$ (400 mg, $\left.1.5 \mathrm{mmol}\right)$. Proses penghabluran semula menggunakan pelarut kloroform dan heksana menghasilkan NiTPP iaitu pepejal berwarna ungu gelap. Formula sebatian: $\mathrm{C}_{47} \mathrm{H}_{37} \mathrm{~N}_{4} \mathrm{Ni}$; Peratusan hasil: $41 \mathrm{mg}$ (75\%); Takat lebur: $>400{ }^{\circ} \mathrm{C}$; $\mathrm{R}_{\mathrm{f}}$ (heksana:kloroform, 2:1): 0.6; $\mathrm{RMN}^{1} \mathrm{H}\left(400 \mathrm{MHz}, \mathrm{CDCl}_{3}\right) \delta_{\mathrm{H}}: 7.71(\mathrm{~m}, 12 \mathrm{H})$, $8.03\left(\mathrm{dd},{ }^{3} \mathrm{~J}_{\mathrm{HH}}=7.2 \mathrm{~Hz},{ }^{4} \mathrm{~J}_{\mathrm{HH}}=1.6 \mathrm{~Hz}, 8 \mathrm{H}\right), 8.76(\mathrm{~s}, 8 \mathrm{H})$; $\operatorname{ULBN}\left(\mathrm{CH}_{2} \mathrm{Cl}_{2}\right): \lambda_{\text {mak }} \mathrm{nm}(\log \varepsilon)=411$ (5.23), 524 (4.10); $\operatorname{ESI-SJ}(\mathrm{m} / \mathrm{z}): 670.2[\mathrm{M}]^{+}$.

\section{SINTESIS SEBATIAN PORFIRIN LOGAM ZN-5,10,15,20- TETRAFENILPORFIRIN (ZnTPP)}

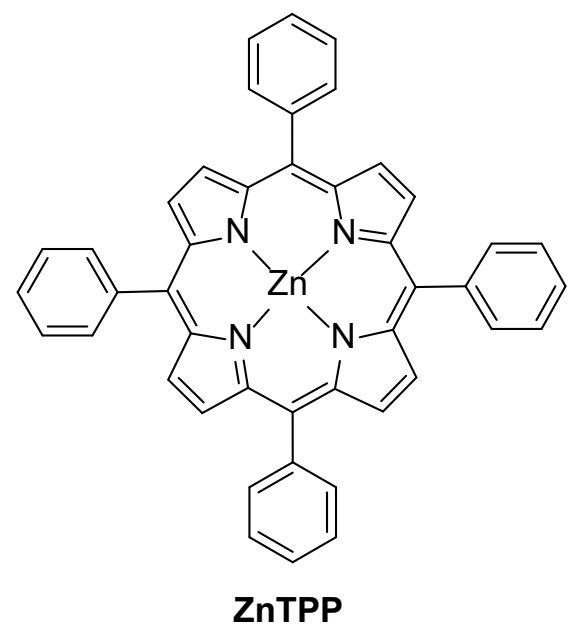

Sebatian ini dihasilkan dengan menggunakan sebatian porfirin (4) (50 mg, $0.08 \mathrm{mmol}$ ) dan $\mathrm{Zn}(\mathrm{Oac})_{2}$ (50 mg, 0.28 $\mathrm{mmol})$. Proses penghabluran semula oleh pelarut DCM dan MeOH menghasilkan ZnTPP iaitu hablur berwarna ungu gelap. Formula sebatian: $\mathrm{C}_{44} \mathrm{H}_{28} \mathrm{~N}_{4} \mathrm{Zn}$; Peratusan hasil: $30 \mathrm{mg}(55 \%)$; Takat lebur: $>400{ }^{\circ} \mathrm{C}$; $\mathrm{R}_{\mathrm{f}}$ (heksana: kloroform, 1:1): 0.5; $\mathrm{RMN}^{1} \mathrm{H}\left(400 \mathrm{MHz}, \mathrm{CDCl}_{3}\right) \delta_{\mathrm{H}}: 7.79$ $(\mathrm{m}, 12 \mathrm{H}), 8.26\left(\mathrm{dd},{ }^{3} \mathrm{~J}_{\mathrm{HH}}=7.2 \mathrm{~Hz},{ }^{4} \mathrm{~J}_{\mathrm{HH}}=1.2 \mathrm{~Hz}\right), 8.98(\mathrm{~s}$, $8 \mathrm{H})$ ppm; ULBN $\left(\mathrm{CH}_{2} \mathrm{Cl}_{2}\right): \lambda_{\text {mak }} \mathrm{nm}(\log \varepsilon)=418$ (5.31), 543 (3.83); ESI-SJ (m/z): $676.2[\mathrm{M}]^{+}$.

\section{ASAI ANTIPLASMODIUM}

P. falciparum K1 (rintang-klorokuina) (MR4: MRA-159) diperoleh daripada Malaria Research and Reference Reagent Resource (MR4), USA. Parasit P. falciparum $\mathrm{K} 1$ dikultur dalam eritrosit manusia jenis $\mathrm{O}$ rhesus positif, O+ (Radfar et al. 2009) menggunakan medium lengkap RPMI 1640 yang mengandungi 10\% Albumax, $2 \mathrm{~g} / \mathrm{L}$ D-glukosa, $2.325 \mathrm{~g} / \mathrm{L}$ natrium bikarbonat, $40 \mathrm{mg} / \mathrm{L}$ gentamisin, hipoksantin dan HEPES. Julat kepekatan porfirin logam yang digunakan adalah $0.001-1000 \mu \mathrm{M}$, manakala julat kepekatan di antara 0.00001-10 $\mu \mathrm{M}$ digunakan bagi klorokuina dan artemisinin. Kawalan positif ialah darah terjangkit- $P$. falciparum K1 manakala kawalan negatif ialah darah normal tanpa jangkitan.

Selepas pengeraman kultur parasit dengan porfirin logam dilakukan selama 48 jam dan piring dibekukan pada suhu $-20^{\circ} \mathrm{C}$ selama 24 jam. Kemudian, kandungan piring dicairkan selama $30 \mathrm{~min}$ di dalam inkubator pada suhu $37^{\circ} \mathrm{C}$ dan dibekukan semula dalam peti sejuk bersuhu $-20^{\circ} \mathrm{C}$ selama $30 \mathrm{~min}$. Kitar pembekuanpencairan diulang sebanyak tiga kali. Pada masa yang sama, piring reagen untuk pengasaian disediakan dengan memasukkan campuran $100 \mu \mathrm{L}$ reagen MALSTAT dengan $25 \mu \mathrm{L}$ reagen NBT-PES ke dalam setiap telaga. Selepas itu, sebanyak $25 \mu \mathrm{L}$ daripada kandungan piring dicampurkan ke dalam piring reagen dan dieram selama sejam pada suhu $37^{\circ} \mathrm{C}$. Bacaan penyerapan diukur selepas sejam dengan alat spektrofotometer (Model SP3000, Fluorostar OPTIMA, USA) pada panjang gelombang 655 nm. Graf lengkuk sigmoid paksi y-peratus pertumbuhan parasit (\%) melawan paksi $\mathrm{x}-$ kepekatan $(\log [\mu \mathrm{M}])$ diplot menggunakan perisian Graph Pad Prism 5. Nilai kepekatan berkesan merencat $50 \%$ pertumbuhan parasit, $\mathrm{EC}_{50}$ ditentukan daripada graf tersebut.

\section{ASAI KESITOTOKSIKAN}

Sel Vero (ATCC: CCL-81), sel normal epitelium ginjal monyet diperoleh daripada American Type Culture Collection (ATCC), USA dan dikultur (Mosmann 1983) dalam medium Dulbecco's Modified Eagle Medium (DMEM) yang dicampurkan dengan 10\% FBS serta 1\% antibiotik penisilin-streptomisin dan $0.1 \%$ amfoterisin bagi mengelakkan pertumbuhan bakteria dan kulat. Sel yang dikultur dalam tabung kultur T-75 ditanggalkan dengan menggunakan tripsin-EDTA. Sebanyak $1 \times 10^{4} \mathrm{sel} /$ $\mathrm{mL}$ dibiakkan pada piring telaga-96 dan dieram selama 24 jam $\left(37^{\circ} \mathrm{C}, 5 \% \mathrm{CO} 2,4 \% \mathrm{O} 2\right.$ dan $95 \%$ kelembapan relatif). Setiap telaga piring yang mengandungi sel dicampurkan dengan porfirin logam dengan tiga replikasi setiap satu kepekatan. Julat kepekatan sebatian porfirin logam yang digunakan adalah 0.001-1000 $\mu \mathrm{M}$, manakala julat kepekatan 0.00001-10 $\mu \mathrm{M}$ digunakan bagi klorokuina dan artemisinin. Campuran sebatian dan sel Vero dieram selama 48 jam. Sel Vero tanpa perlakuan sebatian dijadikan sebagai kawalan. Reagen MTT $(5 \mathrm{mg} / \mathrm{mL})$ disediakan dengan mencampurkan reagen MTT dengan larutan PBS. Sebanyak $10 \mu \mathrm{L}$ reagen MTT $(5 \mathrm{mg} / \mathrm{mL})$ dimasukkan ke dalam setiap telaga dieram selama 3 jam bagi pembentukan formazan ungu. Kemudian, campuran dikeluarkan dan digantikan dengan $100 \mu \mathrm{L}$ pelarut DMSO untuk melarutkan 
pepejal formazan biru yang termendap pada dasar piring telaga-96. Selepas $15 \mathrm{~min}$, pembentukan warna ungu dibaca pada panjang gelombang $540 \mathrm{~nm}$ (Model SP3000, Fluorostar OPTIMA, USA) dan data direkodkan. Graf lengkuk sigmoid paksi y-peratus pertumbuhan sel (\%) melawan paksi x-kepekatan $(\log [\mu \mathrm{M}])$ diplot menggunakan perisian Graph Pad Prism 5 dan nilai kepekatan sitotoksik merencat $50 \%$ pertumbuhan sel, $\mathrm{CC}_{50}$ ditentukan daripada graf.

\section{PENGIRAAN NILAI INDEKS PEMILIHAN}

Penentuan nilai SI bertujuan untuk menilai sama ada tahap perencatan sebatian yang diuji adalah selektif terhadap P. falciparum dan tiada kesan ketoksikan terhadap pertumbuhan sel mamalia. Nilai $\mathrm{EC}_{50}$ dan $\mathrm{CC}_{50}$ yang masing-masing diperoleh daripada graf asai $\mathrm{pLDH}$ dan asai MTT digunakan untuk mengira nilai SI (Sarr et al. 2011).

\section{KEPUTUSAN DAN PERBINCANGAN}

Langkah pertama dalam proses penghasilan sebatian porfirin adalah sintesis bahan pemula dipirometana (1) yang merupakan blok asas dalam penyelidikan porfirin sintetik. Pirola bertindak sebagai nukleofil untuk menyerang kumpulan aldehid. Proses nyahprotonasi menghilangkan cas positif pada nitrogen kumpulan pirola dan mengembalikan sifat aromatik molekul pirola. Kemudian proses pemprotonan berlaku pada kumpulan hidroksil dan molekul air $\left(\mathrm{H}_{2} \mathrm{O}\right)$ akan dikeluarkan. Proses penyahtaksetempatan dalam molekul pirola pada sebatian yang terhasil akan mewujudkan sifat elektrofilik pada sebatian yang membenarkan sebatian pirola yang lain (nukleofil) menyerang untuk membentuk sebatian dipirometana (1).

Sebanyak dua jenis sebatian porfirin jenis $5,15-\mathrm{A}_{2}$ iaitu porfirin yang mempunyai kumpulan penukar ganti yang sama pada dua posisi meso telah dihasilkan iaitu 5,15-difenilporfirin (2) yang mempunyai kumpulan penukarganti fenil dan 5,15-diheksilporfirin (3) dengan kumpulan penukarganti heksil. Sebatian porfirin (2) melibatkan penghasilan satu sebatian yang mempunyai dua jenis karbon meso iaitu dua karbon yang mempunyai kumpulan penukar ganti dan dua karbon yang tidak mempunyai sebarang kumpulan penukar ganti. Tindak balas penyejatan jenis [2+2] menghubungkan dua sebatian pirolik yang mempunyai karbon titian berhubung, membentuk karbon titian yang lain dan seterusnya menghasilkan sebatian makrosiklik porfirin. Tindak balas penyejatan menghasilkan sebatian pengantara porfinogen manakala tindak balas pengoksidaan yang berlaku melalui penambahan agen pengoksidaan menghasilkan sebatian 5,15-difenilporfirin (2).

Asid trifloroasetik digunakan kerana sifat keelektronegatifan florin yang tinggi dan juga sifat penarik elektron kumpulan triflorometil yang melemahkan ikatan oksigen-hidrogen dan seterusnya meningkatkan sifat asid pemangkin. Keasidan bahan pemangkin yang tinggi memudahkan tindak balas pemprotonan pada oksigen dalam aldehid berlaku. Kaedah pemisahan yang digunakan untuk menghasilkan sebatian ini adalah teknik KCV untuk menyingkirkan lebihan agen pengoksidaan, DDQ yang bertukar kehitaman apabila proses pengoksidaan selesai.

Sebatian 5,10,15,20-tetrafenilporfirin (4) iaitu porfirin jenis $\mathrm{A}_{4}$ iaitu porfirin yang mempunyai kumpulan penukar ganti yang sama pada kesemua posisi meso dihasilkan menggunakan kaedah penyejatan Lindsey. Peratusan hasil sebatian yang sedikit berkemungkinan disebabkan langkah yang banyak dan juga berbalik pada setiap langkah mekanisme. Selain itu, proses pengoksidaan sebatian pengantara porfinogen kepada porfirin yang tidak lengkap juga berkemungkinan menjadi faktor jumlah hasil yang rendah berbanding jumlah hasil teori. Peratusan hasil boleh ditingkatkan dengan pemanjangan tempoh proses pengoksidaan untuk memastikan semua sebatian pengantara porfinogen bertukar kepada porfirin. Pencirian spektroskopi RMN ${ }^{1} \mathrm{H}$ dan ${ }^{13} \mathrm{C}$ dilakukan untuk mengesan kehadiran proton atau hidrogen dalam sebatian dipirometana (1), 5,15-difenilporfirin (2), 5,15-diheksilporfirin (3) dan $5,10,15,20$-tetrafenilporfirin (4) yang diperoleh (Fail tambahan).

\section{PENGKOMPLEKSAN SEBATIAN PORFIRIN TERHADAP LOGAM ZINK(II) DAN NIKEL(II)}

Nukleus molekul porfirin merupakan ligan tetradentat yang mempunyai ruang untuk berkoordinat dengan logam pada anggaran diameter 3.7 A. Ini menunjukkan saiz yang dimiliki oleh gelang makrosiklik porfirin membolehkan hampir semua logam berkoordinat dengan porfirin. Selepas kehilangan dua molekul pelarut, kation logam tersolvat berkoordinat pada salah satu nitrogen pada kumpulan pirola. Seterusnya, atom hidrogen pada nitrogen beranjak ke nitrogen pada kumpulan pirola yang bersebelahan. Tindak balas nyahprotonasi pada pirola berlaku serentak dengan pembentukan ikatan antara atom nitrogen pirola dengan ion $\mathrm{Cu}$ manakala tindak balas nyahprotonasi yang seterusnya melengkapkan proses pengkompleksan untuk menghasilkan sebatian metaloporfirin (Mamardashvili et al. 2017). Setiap 
sebatian porfirin bebas bes (2-4) dikomplekskan dengan dua jenis logam iaitu zink(II) dan nikel(II).

Isyarat anjakan kimia yang ditunjukkan adalah berpadanan dengan sebatian porfirin bebas bes kecuali kehilangan anjakan kimia pada bahagian negatif. Isyarat pada julat -2 ppm hingga -3 ppm merupakan anjakan kimia dua proton $\mathrm{NH}$ pada bahagian tengah gelang utama porfirin. Kehilangan puncak ini menunjukkan nyahprotonasi berlaku pada bahagian teras porfirin dan ini membuktikan porfirin berjaya dikomplekskan dengan logam $\mathrm{Zn}(\mathrm{II})$ dan Ni(II). Spektrum RMN bagi keenam porfirin logam yang disintesis dilampirkan dalam fail tambahan.

\section{SPEKTRUM PENYERAPAN ELEKTRONIK SEBATIAN} PORFIRIN BEBAS BES DAN SEBATIAN PORFIRIN LOGAM

Warna fizikal porfirin adalah kesan daripada kadar serapan yang tinggi pada bahagian boleh nampak dalam spektrum elektromagnetik iaitu pada julat 350 hingga $800 \mathrm{~nm}$. Isyarat pada keamatan tinggi iaitu jalur Soret muncul pada julat 400 hingga $450 \mathrm{~nm}$. Jalur Soret ini merupakan kesan daripada peralihan tenaga $\mathrm{S}_{0}$ ke $\mathrm{S}_{2}$ manakala jalur Q yang muncul pada lingkungan 500 hingga $650 \mathrm{~nm}$ merupakan kesan peralihan tenaga $\mathrm{S}_{0} \mathrm{ke}$ $S_{1}$ (Anderson 1994). Keberhasilan tindak balas metalasi ke atas porfirin adalah berdasarkan spektrum ULBN dan jalur Q yang terhasil. Bagi sebatian metaloporfirin, dua jalur Q akan muncul manakala bagi sebatian porfirin bebas bes akan menunjukkan empat jalur Q (Rajah 2). Bagi porfirin bebas bes, jalur Q berpecah kepada dua disebabkan proses pengujaan getaran. Dua jalur terhasil daripada peralihan keadaan asas kepada dua keadaan pengujaan $[\mathrm{Q}(0,0)$ dan $\mathrm{Q}(1,0)]$. Kehadiran $\mathrm{NH}$ pada bahagian tengah gelang bagi porfirin free base memecahkan kesimetrian molekul porfirin dan seterusnya dua jalur terpecah kepada dua menghasilkan empat jalur $\mathrm{Q}$ iaitu $\mathrm{Q}_{\mathrm{x}}(0,0), \mathrm{Q}_{\mathrm{y}}(0,0), \mathrm{Q}_{\mathrm{x}}(1,0)$ dan $\mathrm{Q}_{\mathrm{y}}(1,0)$. Kesemua porfirin bebas bes menunjukkan kemunculan satu jalur Soret dan empat jalur Q manakala sebatian porfirin logam $\mathrm{Zn}$ dan porfirin logam Ni menunjukkan satu jalur Soret dan dua jalur Q (Fail tambahan).
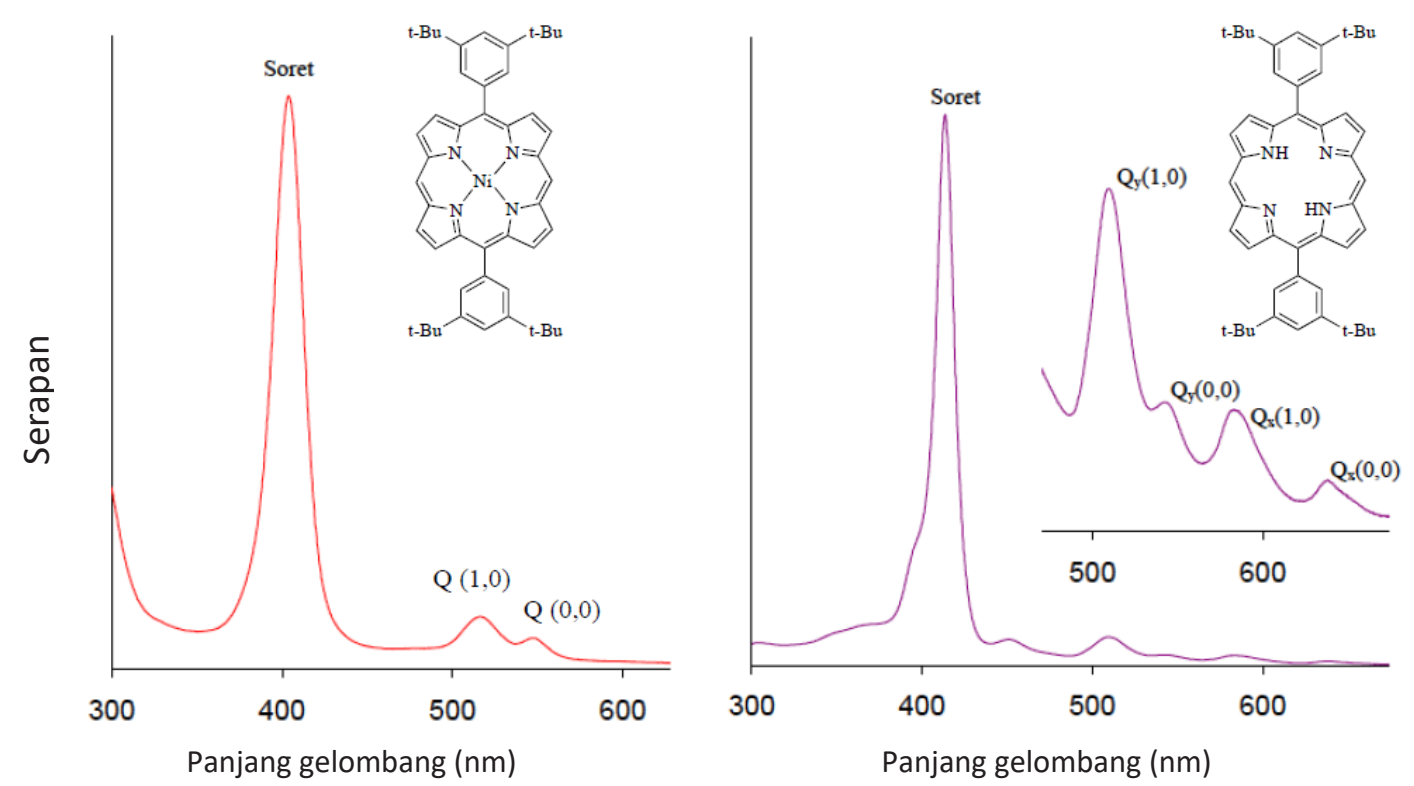

RAJAH 2. Perbezaan spektrum ULBN bagi sebatian porfirin logam dan porfirin bebas bes

\section{AKTIVITI ANTIMALARIA}

Kesan antimalaria enam sebatian porfirin logam yang telah diuji menunjukkan ZnDHP memberi nilai $\mathrm{EC}_{50}$ asai pLDH paling rendah iaitu $21.4 \pm 3.5 \mu \mathrm{M}$, diikuti dengan ZnTPP dengan nilai EC $_{50}$ iaitu 27.7 $\pm 0.4 \mu \mathrm{M}$ dan NiDPP dengan nilai $\mathrm{EC}_{50}$ iaitu $36.0 \pm$ $5.3 \mu \mathrm{M}$. Aktiviti antiplasmodium bagi sebatian tulen dapat dikelaskan mengikut julat nilai berikut; aktiviti antiplasmodium kategori poten adalah $\mathrm{EC}_{50}<1 \mu \mathrm{M}$, aktiviti antiplasmodium kategori aktif adalah $1<\mathrm{EC}_{50}<20$ 
$\mu \mathrm{M}$, aktiviti antiplasmodium kategori sederhana adalah $20<\mathrm{EC}_{50}<100 \mu \mathrm{M}$, aktiviti antiplasmodium kategori lemah adalah $100<\mathrm{EC}_{50}<200 \mu \mathrm{M}$ dan kategori tidak aktif adalah $\mathrm{EC}_{50}>200 \mu \mathrm{M}$ (Dolabela et al. 2008).

Berdasarkan pengkelasan tersebut, ZnDHP, ZnTPP dan NiDPP menunjukkan aktiviti antiplasmodium sederhana, ZnDPP menunjukkan aktiviti yang lemah, manakala NiTPP dan NiDHP adalah tidak aktif (Jadual 1). Klorokuina menunjukkan nilai $\mathrm{EC}_{50}$ sebanyak 380 nM manakala nilai $\mathrm{EC}_{50}$ artemisinin adalah $0.2 \mathrm{nM}$. Kedua-dua dadah rujukan ini adalah poten merencat pertumbuhan $P$. falciparum $\mathrm{K} 1$ secara in vitro selari dengan penggunaannya sebagai rawatan utama antimalaria. Nilai $\mathrm{IC}_{50}$ aktiviti antimalaria klorokuina terhadap P. falciparum K1 telah ditunjukkan sebelum ini dan nilai $\mathrm{EC}_{50}$ kajian ini berada dalam julat yang sama iaitu 200 hingga $300 \mathrm{nM}$ (Dar et al. 2008). Keputusan EC $_{50}$ artemisinin juga adalah selari dengan keputusan kajian lepas iaitu 0.45 hingga $0.60 \mathrm{ng} / \mathrm{mL}$ (Abiodun et al. 2013).

Hasil kajian antiplasmodium ini turut disokong oleh beberapa penemuan kajian lepas yang turut menunjukkan aktiviti sebatian kompleks porfirin logam daripada logam yang berbeza terhadap strain $P$. falciparum iaitu FCR-3 sensitif-klorokuina dan FcB1Columbia rintang-klorokuina. Kajian lepas oleh Begum et al. (2003) menunjukkan sebatian porfirin logam galium protoporfirin IX (GaPPIX), argentum protoporfirin IX (AgPPIX), paladium protoporfirin IX (PdPPIX), mangan protoporfirin IX (MnPPIX), tin protoporfirin IX (SnPPIX), kobalt protoporfirin IX (CoPPIX), kromium protoporfirin IX (CrPPIX), galium deuteroporfirin IX (GaDPIX) dan gallium hematoporfirin IX (GaHPIX) mampu merencat 50\% pertumbuhan $P$. falciparum FCR-3 sensitif-klorokuina pada julat kepekatan antara $15.5 \mu \mathrm{M}$ hingga $190 \mu \mathrm{M}$. Kajian antimalaria lain pula mendapati bahawa sebatian mangan porfirin logam, MnTMPS dan MnTPPS merencat pertumbuhan $P$. falciparum FcB1Columbia rintang-klorokuina dalam julat antimalaria poten iaitu nilai $\mathrm{IC}_{50}$ antara $104 \mathrm{nM}$ hingga $196 \mathrm{nM}$ (Benoit-Vical et al. 2000). Ini mencadangkan bahawa sebatian porfirin logam adalah kumpulan sebatian kimia yang wajar dikembangkan bagi pencarian dadah antimalaria untuk menentang kes kerintangan parasit pada dadah antimalaria pada masa akan datang.

JADUAL 1. Keputusan kesan antiplasmodium dan kesitotoksikan sebatian porfirin logam

\begin{tabular}{|c|c|c|c|c|}
\hline \multirow[b]{2}{*}{ Bil. } & \multirow[b]{2}{*}{ Sebatian porfirin logam } & Aktiviti antiplasmodium & Aktiviti kesitotoksikan & \multirow{2}{*}{ Indeks pemilihan (SI), } \\
\hline & & $\begin{array}{c}\text { P. falciparum } \mathrm{K} 1 \\
\text { (rintang-klorokuina) } \\
\mathrm{EC}_{50}(\mu \mathrm{M}) \pm \mathrm{SP}\end{array}$ & $\begin{array}{c}\text { Sel Vero } \\
\text { (Sel normal mamalia) } \\
\mathrm{CC}_{50}(\mu \mathrm{M}) \pm \mathrm{SP}\end{array}$ & \\
\hline 1 & NiDPP & $36.0 \pm 5.3$ & $97.7 \pm 20.6$ & 2.7 \\
\hline 2 & ZnDPP & $157.0 \pm 9.2$ & $2699.5 \pm 84.2$ & 17.2 \\
\hline 3 & NiDHP & $551.9 \pm 69.9$ & $12.1 \pm 5.1$ & 0.1 \\
\hline 4 & ZnDHP & $21.4 \pm 3.5$ & $582.2 \pm 70.7$ & 27.2 \\
\hline 5 & NiTPP & $395.0 \pm 28.6$ & $22.1 \pm 1.9$ & 0.1 \\
\hline 6 & ZnTPP & $27.7 \pm 0.4$ & $330.9 \pm 84.1$ & 11.9 \\
\hline 7 & Klorokuina & $380 \mathrm{nM}$ & 308.4 & 811.6 \\
\hline 8 & Artemisinin & $0.2 \mathrm{nM}$ & 466.1 & $>2000$ \\
\hline
\end{tabular}


Penentuan kesitotoksikan sebatian porfirin logam melalui asai MTT telah dijalankan terhadap sel Vero. ZnDHP, ZnDPP dan ZnTPP menunjukkan nilai $\mathrm{CC}_{50}$ terhadap sel Vero pada julat $330 \mu \mathrm{M}$ hingga $2699 \mu \mathrm{M}$, manakala NiDHP, NiTPP dan NiDPP dalam julat 12 $\mu \mathrm{M}$ hingga $97 \mu \mathrm{M}$. Sesuatu sebatian tulen dikelaskan toksik jika menunjukkan nilai $\mathrm{CC}_{50}<20 \mu \mathrm{M}$, kurang toksik jika nilai $\mathrm{CC}_{50}$ dalam julat $20<\mathrm{CC}_{50}<100 \mu \mathrm{M}$, tidak toksik jika nilai $\mathrm{CC}_{50}$ dalam julat $\mathrm{CC}_{50}>100 \mu \mathrm{M}$ (Tanamatayarat et al. 2011). Analisis kesitotoksikan sel Vero yang diperoleh menunjukkan NiDHP adalah toksik kepada sel Vero manakala NiTPP dan NiDPP memberi kesan kesitotoksikan yang lemah terhadap pertumbuhan sel Vero. ZnDHP, ZnDPP dan ZnTPP pula tidak menunjukkan kesan toksik kepada sel Vero (Jadual 1). Hasil keputusan asai kesitotoksikan menunjukkan aktiviti sitotoksik sebatian porfirin logam $\mathrm{Ni}$ adalah lebih toksik daripada sebatian porfirin logam $\mathrm{Zn}$. Hasil asai kesitotoksikan kajian lepas menunjukkan sebatian ZnTMeOPP dan CuTMeOPP terhadap sel HeLa, 8MGBA, Lep-3, dan MDBK berada dalam julat sitotoksik iaitu 36 hingga $79 \mu \mathrm{g} / \mathrm{mL}$ yang mencadangkan bahawa kesan kesitotoksikan sel adalah bergantung kepada kumpulan kompleks logam, kepekatan sebatian dan jenis sel yang diuji (Alexandrova et al. 2018). Kedua-dua dadah rujukan antimalaria menunjukkan nilai $\mathrm{CC}_{50}$ yang tidak toksik dengan klorokuina dan artemisinin merencat $50 \%$ pertumbuhan sel Vero pada kepekatan $308.4 \mu \mathrm{M}$ dan 466.1 $\mu \mathrm{M}$. Keputusan ini disokong oleh kajian lepas yang menunjukkan kesan kesitotoksikan hampir sama terhadap sel Vero (Filho et al. 2009; Kumar et al. 2009).

Nilai SI sebatian kimia yang melebihi 10 menunjukkan aktiviti antiplasmodium adalah memilih terhadap parasit yang diuji (Sarr et al. 2011). Nilai SI bagi ZnDHP, ZnDPP dan ZnTPP adalah melebihi 10, manakala NiDHP, NiTPP dan NiDPP mempunyai nilai SI kurang daripada 10 . Ini mencadangkan bahawa tindakan perencatan parasit oleh sebatian porfirin logam ZnDHP, ZnDPP dan ZnTPP adalah selektif dan tidak toksik terhadap sel mamalia. Nilai indeks pemilihan yang ditunjukkan oleh klorokuina dan artemisinin adalah 811.6 dan $>2000$, bertepatan dengan fungsi tindakan yang selektif terhadap pertumbuhan parasit dan kurang toksik terhadap sel mamalia. Nilai SI klorokuina dan artemisinin juga bergantung kepada jenis strain Plasmodium sp. yang diuji. Kajian lepas menunjukkan nilai klorokuina masing-masing SI $>298$ dan $>42$ terhadap pertumbuhan $P$. falciparum sensitif-klorokuina (D6) dan rintangklorokuina (W2), manakala artemisinin menunjukkan nilai SI yang lebih tinggi terhadap $P$. falciparum sensitifklorokuina (D6) dan rintang-klorokuina (W2) masing- masing iaitu $>476$ dan >1400 (Atheaya et al. 2008; Kumar et al. 2009).

Walaupun kajian antimalaria porfirin logam pernah dilaporkan sebelum ini, tetapi aktiviti antimalaria porfirin logam ZnDHP, ZnTPP dan NiDPP terhadap strain rintang-klorokuina, K1 adalah pertama kali dilaporkan. Porfirin logam adalah perencat poten untuk pempolimeran hem bagi menghalang ketoksikan hem terhadap parasit. Parasit malaria mencernakan hemoglobin yang ada di vakuol pencernaan kepada hem melalui tindak balas enzim protease. Pempolimeran hem menukarkan bentuk toksik hem kepada hemozoin melalui ikatan hidrogen intramolekul. Kajian lepas turut mencadangkan sebatian protoporfirin logam seperti CrPPIX, CoPPIX, MnPPIX, CuPPIX, MgPPIX, ZnPPIX dan SnPPIX mampu merencat pembentukan hemozoin dengan berkesan (Begum et al. 2003). Pempolimeran hem juga adalah mekanisme sasaran sebatian klorokuina dan artemisinin. Klorokuina membentuk kompleks dengan $\beta$-hematin dan merencat penyambungan rantaian hemozoin (Sullivan et al. 1996). Ion logam memainkan peranan signifikan dalam menghalang pembentukan hemozoin. ZnDHP, ZnTPP dan NiDPP menunjukkan kesan antimalaria sederhana yang berkemungkinan bertindak melalui mekanisme sasaran pempolimeran hem melalui pembentukan ikatan $\pi-\pi$ heteroporfirin logam.

\section{KESIMPULAN}

Enam metaloporfirin iaitu NiDDHP, NiDPP, NiTPP, ZnDHP, ZnDPP dan ZnTPP berasaskan porfirin meso bebas bes 5,15-difenilporfirin (2), 5,15-diheksilporfirin (3) dan 5,10,15,20-tetrafenilporfirin (4) dihasilkan dan dicirikan secara spektroskopi. Aktiviti antiplasmodium dan kesitotoksikan secara in vitro sebatian ini dinilai terhadap strain rintang-klorokuina, K1. ZnDHP, ZnTPP dan NiDPP memberikan aktiviti antimalaria sederhana yang berpotensi untuk bertindak ke atas tapak jalan sintesis hemozoin. Sebatian porfirin logam wajar dijadikan sebagai asas kepada perkembangan dadah antimalaria terutama ke atas strain parasit yang rintang. Asai in vitro pempolimeran hem pada darah terinfeksi K1 pada masa hadapan boleh membuktikan metaloporfirin bertindak secara langsung ke atas tapak jalan sintesis hemozoin.

\section{PENGHARGAAN}

Dana penyelidikan disediakan daripada Kementerian Pendidikan Malaysia melalui geran bernombor FRGS/1/2019/STG01/UKM/02/3 dan Jabatan Sains Kimia, Fakulti Sains dan Teknologi, Universiti Kebangsaan Malaysia untuk kemudahan fasiliti yang disediakan. 


\section{RUJUKAN}

Abiodun, B., Salami, A., Matthew, O. \& Odedokun, S. 2013. Potential impacts of afforestation on climate change and extreme events in Nigeria. Climate Dynamics 41. doi:10.1007/s00382-012-1523-9.

Alexandrova, R., Kalfin, R., Tudose, R. \& Fagadar-Cosma, E. 2018. Comparative cytotoxicity assays performed using a free porphyrin and its $\mathrm{Zn}(\mathrm{II}), \mathrm{Co}(\mathrm{II})$ and $\mathrm{Cu}()$ Complexes. Influence of optical and aggregation properties. Studia Universitatis Babeș-Bolyai Chemia 63: 65-77. doi:10.24193/ subbchem.2018.4.05.

Ali, A., Sudi, S., Sidek, H., Embi, N. \& Basir, R. 2017. The antimalarial effect of curcumin is mediated by the inhibition of glycogen synthase kinase-3 3 . Journal of Medicinal Food 20: 152-161. doi:10.1089/jmf.2016.3813.

Anderson, H.L. 1994. Conjugated porphyrin ladders. Inorganic Chemistry 33(5): 972-981. doi:10.1021/ic00083a022.

Atheaya, H., Khan, S.I., Mamgain, R. \& Rawat, D.S. 2008. Synthesis, thermal stability, antimalarial activity of symmetrically and asymmetrically substituted tetraoxanes. Bioorganic \& Medicinal Chemistry Letters 18(4): 1446-1449. doi:https://doi.org/10.1016/j.bmcl.2007.12.069.

Banziger, S.D. \& Ren, T. 2019. Syntheses, structures and bonding of 3D metal alkynyl complexes of cyclam and its derivatives. Journal of Organometallic Chemistry 885: 39-48. doi:10.1016/j.jorganchem.2019.01.024.

Begum, K., Kim, H.S., Kumar, V., Stojiljkovic, I. \& Wataya, Y. 2003. In vitro antimalarial activity of metalloporphyrins against Plasmodium falciparum. Parasitology Research 90(3): 221-224. doi:10.1007/s00436-003-0830-9.

Benoit-Vical, F., Robert, A. \& Meunier, B. 2000. In vitro and in vivo potentiation of artemisinin and synthetic endoperoxide antimalarial drugs by metalloporphyrins. Antimicrobial Agents and Chemotherapy 44(10): 2836-2841. doi:10.1128/ AAC.44.10.2836-2841.2000.

Cole, K.A., Ziegler, J., Evans, C.A. \& Wright, D.W. 2000. Metalloporphyrins inhibit $\beta$-hematin (hemozoin) formation. Journal of Inorganic Biochemistry 78(2): 109-115. https:// doi.org/10.1016/S0162-0134(99)00216-0.

Dar, O., Khan, M.S. \& Adagu, I. 2008. The potential use of methotrexate in the treatment of falciparum malaria: in vitro assays against sensitive and multidrug-resistant Falciparum strains. Japanese Journal of Infectious Diseases 61(3): 210-211.

Dive, D. \& Biot, C. 2008. Ferrocene conjugates of chloroquine and other antimalarials: The development of ferroquine, a new antimalarial. ChemMedChem 3(3): 383-391. doi:10.1002/ cmdc. 200700127.

Dolabela, M., Oliveira, S., Nascimento, J., Peres, J., Wagner, H., Póvoa, M. \& De Oliveira, A. 2008. In vitro antiplasmodial activity of extract and constituents from Esenbeckia febrifuga, a plant traditionally used to treat malaria in the Brazilian Amazon. Phytomedicine: International Journal of Phytotherapy and Phytopharmacology 15: 367-372. doi:10.1016/j.phymed.2008.02.001.
Fairhurst, R.M. \& Dondorp, A.M. 2016. Artemisinin-resistant Plasmodium falciparum malaria. Microbiology Spectrum 4(3): 1-16. doi:10.1128/microbiolspec.EI10-0013-2016.

Filho, A.A., Resende, D.O., Fukui, M.J., Santos, F.F., Pauletti, P.M., Cunha, W.R., Silva, M.L.A., Gregório, L.E., Bastos, J.K. \& Nanayakkara, N.P.D. 2009. In vitro antileishmanial, antiplasmodial and cytotoxic activities of phenolics and triterpenoids from Baccharis dracunculifolia D.C. (Asteraceae). Fitoterapia 80: 478-482. doi:10.1016/j. fitote.2009.06.007.

Hamed, K. \& Stricker, K. 2016. Tackling the problems associated with antimalarial medicines of poor quality. Current Topics in Malaria. InTech. doi:10.5772/64671. hlm. 285-303.

Hubin, T.J., Amoyaw, P.N.A., Roewe, K.D., Simpson, N.C., Maples, R.D., Carder Freeman, T.N., Cain, A.N., Le, J.G., Archibald, S.J., Khan, S.I., Tekwani, B.L. \& Faruk Khan, M.O. 2014. Synthesis and antimalarial activity of metal complexes of cross-bridged tetraazamacrocyclic ligands. Bioorganic and Medicinal Chemistry 22(13): 3239-3244. doi:10.1016/j.bmc.2014.05.003.

Hussin, N., Lim, Y.A.L., Goh, P.P., William, T., Jelip, J. \& Mudin, R.N. 2020. Updates on malaria incidence and profile in Malaysia from 2013 to 2017. Malaria Journal 19(1): 55. doi:10.1186/s12936-020-3135-x.

Kumar, N., Khan, S.I., Sharma, M., Atheaya, H. \& Rawat, D.S. 2009. Iodine-catalyzed one-pot synthesis and antimalarial activity evaluation of symmetrically and asymmetrically substituted 3,6-diphenyl[1,2,4,5]tetraoxanes. Bioorganic \& Medicinal Chemistry Letters 19(6): 1675-1677. doi:https:// doi.org/10.1016/j.bmcl.2009.01.103.

Lindsey, J.S., Schreiman, I.C., Hsu, H.C., Kearney, P.C. \& Marguerettaz, A.M. 1987. Rothemund and Adler-Longo reactions revisited: Synthesis of tetraphenylporphyrins under equilibrium conditions. The Journal of Organic Chemistry 52(5): 827-836. DOI: 10.1021/jo00381a022.

Li, K., Zhang, J., Zhang, J.J., Zhang, Z.W., Zhuang, Z.J., Xiao, D., Lin, H.H. \& Yu, X.Q. 2008. Ferrocene-bridging dinuclear cyclen copper(II) complexes as high efficient artificial nucleases: Design, synthesis and interaction with DNA. Applied Organometallic Chemistry 22(5): 243-248. doi:10.1002/aoc.1384.

Li, Y. 2012. Qinghaosu (artemisinin): Chemistry and pharmacology. Acta Pharmacologica Sinica 33(9): 11411146. doi:10.1038/aps.2012.104.

Mamardashvili, G., Zhdanova, D., Mamardashvili, N., Koifman, O. \& Dehaen, W. 2017. Catalytic and inhibiting effect of amino acids on the porphyrin metallation reactions. Journal of Porphyrins and Phthalocyanines 21: 671-679. doi:10.1142/ S1088424617500663.

Mamat, N., Abdullah, H., Hapidin, H. \& Mokhtar, N. 2020. Gallic acid and methyl gallate enhance antiproliferative effect of cisplatin on cervical cancer (HeLa) cells. Sains Malaysiana 49: 1107-1114. doi:10.17576/jsm-2020-4905-15.

Mosmann, T. 1983. Rapid colorimetric assay for cellular growth and survival: Application to proliferation and cytotoxicity assays. Journal of Immunological Methods 65(1): 55-63. doi:https://doi.org/10.1016/0022-1759(83)90303-4. 
Navarro, M., Castro, W. \& Biot, C. 2012. Bioorganometallic compounds with antimalarial targets: Inhibiting hemozoin formation. Organometallics 31(16): 5715-5727. doi:10.1021/ om300296n.

Okebe, J., Bojang, K. \& D'Alessandro, U. 2014. Use of artemisinin and its derivatives for the treatment of Malaria in children. Pediatric Infectious Disease Journal 33(5): 522524. doi:10.1097/INF.0000000000000306.

Peter, S. \& Aderibigbe, B.A. 2019. Ferrocene-based compounds with antimalaria/anticancer activity. Molecules 24(19). doi:10.3390/molecules24193604.

Radfar, A., Mendez, D., Moneriz, C., Linares, M., Marín-García, P., Puyet, A., Diez, A. \& Bautista, J.M. 2009. Synchronous culture of Plasmodium falciparum at high parasitemia levels. Nature Protocols 4: 1899-1915. doi:10.1038/nprot.2009.198.

Sarr, O., Perrotey, S., Fall, I., Ennahar, S., Zhao, M., Diop, Y.M., Candolfi, E. \& Marchioni, E. 2011. Icacina senegalensis (Icacinaceae), traditionally used for the treatment of malaria, inhibits in vitro Plasmodium falciparum growth without host cell toxicity. Malaria Journal 10: 85. doi:10.1186/14752875-10-85.

Sullivan, D.J., Gluzman, I.Y., Russell, D.G. \& Goldberg, D.E. 1996. On the molecular mechanism of chloroquine's antimalarial action. Proceedings of the National Academy of Sciences of the United States of America 93(21): 1186511870.

Summers, K.L. 2019. A Structural chemistry perspective on the antimalarial properties of thiosemicarbazone metal complexes. Mini-Reviews in Medicinal Chemistry 19(7): 569-590. doi:10.2174/1389557518666181015152657.

Tanamatayarat, P., Sotanaphun, U. \& Poobrasert, O. 2011. Thai plants from Doi Tung: Brine shrimp lethality, antioxidative activity and combination effect with L-ascorbic acid. Natural Product Research 26: 919-925. doi:10.1080/14786419.201 0.534469 .

Yong, A.S.J., Navaratnam, P., Kadirvelu, A. \& Pillai, N. 2018. Reemergence of malaria in Malaysia: A review article. OALib 5(2): 1-16. doi:10.4236/oalib.1104298.
Zakaria, N.H., Hassan, N.I. \& Wai, L.K. 2020. Molecular docking study of the interactions between Plasmodium falciparum lactate dehydrogenase and 4-aminoquinoline hybrids. Sains Malaysiana 49(8): 1905-1913. doi:10.17576/jsm-20204908-12.

Nuur Haziqah Mohd Radzuan, Nur Aqilah Zahirah Norazmi, Amatul Hamizah Ali, Muntaz Abu Bakar \& Nurul Izzaty Hassan* Department of Chemical Sciences

Faculty of Science and Technology

Universiti Kebangsaan Malaysia

43600 UKM Bangi, Selangor Darul Ehsan

Malaysia

Hani Kartini Agustar

Department of Earth Science and Environment

Faculty of Science and Technology

Universiti Kebangsaan Malaysia

43600 UKM Bangi, Selangor Darul Ehsan

Malaysia

Mohd Ridzuan Mohd Abd Razak

Herbal Medicine Research Centre Institute for Medical Research

National Institute of Health (NIH) Complex

Ministry of Health Malaysia

40170 Shah Alam, Selangor Darul Ehsan

Malaysia

*Pengarang untuk surat-menyurat; email: drizz@ukm.edu.my

Diserahkan: 26 Oktober 2020

Diterima: 14 Februari 2021 